\title{
TYPE 2 DIABETES RISK FACTORS AMONG THE UNEMPLOYED
}

\author{
Remigiusz Filarski \\ Department of Prophylaxis of Metabolic Diseases in Białystok \\ Institute of Animal Reproduction and Food Research Polish Academy of Sciences
}

Filarski R. (2014), Type 2 diabetes risk factors among the unemployed. Health Problems of Civilization, 4 (8), p. 4-8

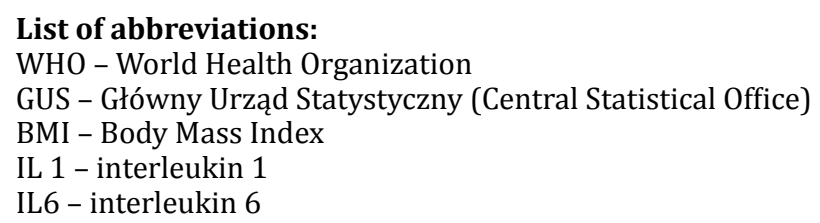

Summary: Unemployment is a significant social problem which has numerous negative health consequences. Findings of numerous researches provide data on the range of the consequences of unemployment with risk of health deterioration being one of the most important. Unemployment remains an area of interest for the following fields of science: psychology, economics, sociology. More and more researches prove that there is a link between the increase of disease occurrence and death rate and long-term unemployment. Both in Poland and all over the world a steady increase in the incidence of type 2 diabetes is being observed. World Health Organization (WHO) estimates that, taking into consideration present dynamics of changes, in 2025 there will be 300 million people diagnosed with diabetes. That is why a diabetes epidemic is such a topical issue, and according to some epidemic data this epidemic is starting to reach Poland as well. Data provided by IDF (International Diabetes Federation) show that in Poland the percentage of diabetes patients is $9,1 \%$ of the whole population and it is a little higher than the European average $(8,6 \%)$. It is predicted that by 2015 the percentage will rise to $11 \%$. Identification of adverse health behaviors and introducing actions promoting health in a given population group can prove to be beneficial for the present condition of members of a given group as well as decrease the risk connected with the occurrence of diseases associated with the progress of civilization in the future. The aim of the article is to indicate type 2 diabetes risk factors among the unemployed in Poland.

Keywords: unemployment, type 2 diabetes, risk factors

\section{Introduction}

Unemployment still remains a significant social problem. Findings of numerous researches provide data on the range of the consequences of unemployment with risk of health deterioration being one of the most important. Unemployment remains an area of interest for the following fields of science: psychology, economics, sociology. More and more researches prove that there is a link between the increase of disease occurrence and death rate and longterm unemployment (Martikainen 1996, Zagożdżon 2008).

According to the International Labour Organization an unemployed person is someone who meets three conditions simultaneously: he/she is without employment or self-employment for more than one hour within a short period of time (one day or one week), he/she is available to take up employment and looks for a job (Kostrzewski 2008).

Both in Poland and all over the world a steady increase in the disease occurrence and the incidence of type 2 diabetes is being observed. According to World Health Organization (WHO) there were 135 million type 2 diabetes patients and taking into consideration present dynamics of changes it is estimated that in 2025 this number will increase by $122 \%$ and will reach around 300 million. It must be added that greater dynamics of changes is expected in developing countries where the predicted increase in the incidence of type 2 diabetes may rise to $170 \%$. The reason for this may be the societies of these countries adopting so called the way of life in the West. It should also be remembered that structural changes within economy, globalization, political transformations bring also negative social consequences, which results in mounting social stratification and unemployment (WHO 1998, Kołodko 2002).

Adress for correspondence: Remigiusz Filarski, Department of Prophylaxis of Metabolic Diseases in Białystok, M. Skłodowskiej-Curie 24 St., 15-276 Białystok, e-mail: r.filarski@pan.olsztyn.pl, phone: (85) 7468818

Tables: 2 Figures: 0 References: 31 Full-text PDF www.hpc.edu.pl Copyright (C Pope John Paul II State School of Higher Education in Biała Podlaska, Sidorska 95/97, 21-500 Biała Podlaska Indexation: Index Copernicus, Database AGRO, ProQuest, Polish Ministry of Science and Higher Education. This is an open-access article distributed under the terms of the Creative Common Attribution Non-commercial license (http://creativecommons.org/licenses/by-nc/3.0), which permits use, distribution and reproduction in any medium, provided the original works is properly cited, the use is non-commercial and is otherwise in compliance with the license. 
Results of researches show that unemployment and worsening living conditions have a negative impact on health condition and forming proper health behaviors. On the other hand the research shows that in comparison with the control group, a higher percentage of diabetes patients was economically inactive (i.e. unable to work, sick or kept house), which is a vicious circle and may lower the quality of life and have a destructive impact on health (Robinson 1989). Thus it seems appropriate to bring up a discussion and broaden our knowledge about the risk factors of some chosen diseases associated with the progress of civilization among the unemployed in Poland with regard to the size of population group that these people constitute.

According to Central Statistical Organization between the years 2010-2013 in Poland the percentage of the unemployed fluctuated around 11-13\% remaining on a relatively high level. In the Podlasie region the unemployment rate reached 14,9\% in 2013 where 70000 people were without employment.

\section{Material and methods}

Body composition of the unemployed from the Podlasie region was assessed in the research. The research included 81 people (64 women and 17 men) between 21-54 years of age from five districts: Zambrowo District, Sokółka District, Sejny District, Kolno District and Hajnówka District and were registered in District Employment Agencies. Measurement of body composition was conducted with the use of the analyzer TANITA BC 418 MA in accordance with the producer recommendation. The following parameters were assessed: actual body mass, BMI, mass and percentage content of fatty tissue, water content, fat-free body mass and basal metabolism. Results were related to the standards of IŻŻ (Instytut Żywności I Żywienia - Food and Nutrition Institute) in Warsaw. The shortest period of unemployment among the subject population was 12 months.

\section{Results}

$16 \%$ of subjects $(n=13)$ were diagnosed with obesity with BMI $>30,27 \%(n=22)$ of subjects were overweight (BMI 25-30), around 49\% (n=40) had normal body mass (BMI 20-25) and 7\% of people had BMI < 18,5 which is classified as underweight $(n=6)$. Table 2 presents average results as well as minimum and maximum values in a subject group and in individual cities.

\section{Discussion}

Being one of the major social problems, unemployment produces numerous negative health consequences (Latalski 2004, GUS 2010). It result from the fact that long-term unemployment entails growing financial problems and impoverished household. Lack of steady income force families to constant sacrifices and limitations as far as satisfying basic needs is concerned (Latalski 2002, 2004, Żyto-Uramowska 2003).

It is a common fact that according to Lalonde's health fields describing factors determining health condition of a population, a lifestyle and connected with it health behaviors have a decisive influence on a health condition. Health behaviors of the unemployed must be examined in social and cultural context where an economic factor is a major but obviously not the only determinant of a person's behavior. Kostrzewski's research shows that almost $80 \%$ of the unemployed declared that the their household budget did not allow them to satisfy their basic needs such as food, medication or clothes (Kostrzewski 2008). In literature there is little information about the lifestyle and eating habits among the unemployed. According to Latalski et al. almost half of the unemployed (around 45\%) has fewer than three meals a day. They are deficient in vegetables and fruit and high in protein products. Almost 38\% of respondents has three main meals regularly but this diet is monotonous, including only basic food products (Latalski 2003).

Previous researches conducted by numerous centres show that type 2 diabetes is closely related to such risk factors as improper eating habits, excessive body mass, low physical activity, smoking, alcohol abuse etc. (WHO 2000; Eliasson 2003; Socha 2003; Kłosiewicz-Latoszek 2011; Przybyłowicz 2008; IASO 2009). In literature there is no information about the frequency of overweight and obesity occurrence among the unemployed in Poland. The research showed that overweight and obesity causes many health problems and is one of the major diabetes type 2 risk factors $(3,9,23,30)$. However it should be remembered that BMI, on the basis of which degrees of obesity are classified, does not provide information about the amount and distribution of fat in an organism. An average percentage content of fatty tissue in the subject group was $28,76 \pm 10,26$. In normal conditions an adult man's fat mass should not exceed $18 \%$ of his actual body mass and an adult woman's fat mass should not exceed $28 \%$ of her actual body mass. In a male group an average percentage content of fatty tissue was $18,46 \pm 7,29$ and It was close to standard values. In female group it was $31,5 \% \pm$ 9,17 and it exceeded normal values. It should be noticed that $64 \%$ of women $(n=41)$ were found to have an excessive fat cover (FAT\% > 28) and in 30 cases fatty tissues made more than $32 \%$ of their total body mass which, according to Tatoń's classification, fulfils the obesity criteria. It is common knowledge that obesity constitutes a hazard to health and life. The 
most dangerous for obese people is diabetes, hypertension, hyperlipidemia, atherosclerosis and ischaemic heart disease (WHO 2000). As the research on health condition of the unemployed shows the biggest health problems among the respondents are the alimentary canal diseases headed by gastric and duodenum ulcer ( $41 \%$ of respondents), then mental disorder (30\%) and cardiovascular diseases (21\%) such as hypertension, myocardial infarction and atherosclerosis. It must be added that obesity is connected with risk factors of hypertension, atherosclerosis and ischaemic heart disease and they all constitute metabolic syndrome. The main reason for the above mentioned disorders is insulin resistance a predisposing factor to type 2 diabetes (Pacholczyk 2008).

Losing a job is a very difficult and complex situation and not only due to much poorer financial situation but also physical and mental state of the unemployed. The research shows that the respondents had pessimistic feelings right after losing employment. Every fifth person feels indifference and helplessness. The most common feelings of the unemployed are feeling of injustice, breakdown, terror and despair, which may cause or intensify already existing depressive state. Montgomery et al. showed in their research that unemployment is a risk factor of depression which needs medical attention even among people who have never been diagnosed with the susceptibility to mental diseases (Dolecka 1997; Montgomery 1999).

Carnethon's meta-analysis was used to assess the link between depression and diabetes and it was proved that depression increases the risk of diabetes by 37\%. It partly results from the fact that some diabetes risk factors are more common among people with depression. The factors are lack of physical activity, obesity, smoking. We should also take into consideration the negative impact of depressive disorders on glucose metabolism for example increase in secretion of counter-regulating hormones (for example catecholamine, glucagon, glucocorticoids), increase in the activity of inflammatory factors (interleukin 1 - IL1, interleukin 6 - IL6); the disorders contribute to the increase in insulin resistance. It must be added that there are risk factors of depression which diabetes patients have in common i.e. a young age, bad financial situation, low level of education, female sex, singleness (Talbot 2000; Musselman 2003; Katon 2004; Carnethon 2007).

Undoubtedly chronic depressive states, stress connected with being unemployed lead to somatic symptoms which influence the standard of living. Latalski's research shows that almost half of the unemployed experienced psychosomatic ailments such as headache, stomachache, nausea and vomiting. Such symptoms were observed mainly among people between 21-29 years of age. 1/5 of the respondents, mainly between 30-39 years of age, experienced lack of appetite and excessive losing weight. 15\% of the respondents reported pain in their chest and dyspnea at rest. Such ailments were reported mainly by people over 50 years of age. English researchers showed that unemployed men had more medical appointments, took more medication and spent more time ill in bed in comparison with employed people, though the number of diagnosed illnesses in both group was similar (Linn 1985, Latalski 2003).

In addition, in case of people whose unemployment is long-lasting, the authors point at numerous anti-health activities connected with the decrease in physical activity, smoking and alcohol abuse. According to the same research almost $65 \%$ of respondents smoke every day, $28,5 \%$ occasionally and $7 \%$ do not smoke at all. Around $25 \%$ of the unemployed drink alcohol every day, almost 33\% drink a few times in a week, $15 \%$ a few times in a month, and only $8 \%$ of the unemployed do not drink at all. Research conducted by Kostrzewski shows that the level of physical activity among the unemployed was very low. More than half of the respondents did not practice any sport or any other form of physical activity. $40 \%$ of respondents said that being unemployed had a negative influence on their physical activity, and only $10 \%$ of the unemployed reported higher level of physical activity during the period of unemployment. The interestingthingis that the decreaseinthelevel ofphysicalactivitywasmorecommonamongwomenthanmen(table1). In must be added that as the period of unemployment prolongs, the above mentioned negative health behaviors intensify. Participation of smokers, being unemployed for more than two years, was higher in comparison with those unemployed for a shorter period of time (respectively 51,3\% and 45,6\%). What is more, almost $37 \%$ of respondents admit that while being unemployed they smoke more cigarettes in comparison with the time when they had a job (Latalski 2003, 2004, Kostrzewski 2008).

\section{Conclusions}

A lot is known about the health condition of Polish population taking into consideration differences concerning gender, age or region but there is still little information about health condition of the unemployed. Overweight and obesity may lead to lower standard of living in this population group. Researches on the differences in health condition and the link between poverty and health condition are being developed all the time. Literature provides materials concerning health of the unemployed in the economic and psychological and sociological contexts but they are based mainly on surveys. Nevertheless this study draws attention to a problem which may become the basis for further research into health condition of the unemployed. 
Table 1. Changes in physical activity in the period of unemployment [10]

\begin{tabular}{|c|c|c|c|c|c|c|}
\hline \multirow{2}{*}{ Changes in physical activity in the period of unemployment } & \multicolumn{2}{|c|}{ Men } & \multicolumn{2}{|c|}{ Women } & \multicolumn{2}{|c|}{ Total } \\
\hline & $\mathrm{N}$ & $\%$ & $\mathrm{~N}$ & $\%$ & $\mathrm{~N}$ & $\%$ \\
\hline Physical activity increased & 8 & 15,4 & 4 & 5,9 & 12 & 10 \\
\hline Physical activity decreased & 19 & 36,5 & 29 & 42,6 & 48 & 40 \\
\hline Physical activity did not change & 25 & 48,1 & 35 & 51,5 & 60 & 60 \\
\hline Total & 52 & 100 & 68 & 100 & 120 & 100 \\
\hline
\end{tabular}

Table 2. Average results in a subject group

\begin{tabular}{|c|c|c|c|c|c|c|c|c|c|}
\hline & age & height & body mass $(\mathrm{kg})$ & bmi & bmr (kcal) & fat $\%$ & fat mass $(\mathrm{kg})$ & lbm (kg) & twc (kg) \\
\hline \multicolumn{10}{|l|}{ Sokółka } \\
\hline Average & $29,41 \pm 10,09$ & $168,29 \pm 7,40$ & $76,08 \pm 19,09$ & $27,06 \pm 7,53$ & $1529,76 \pm 275,05$ & $33,53 \pm 11,99$ & $26,65 \pm 14,24$ & $49,49 \pm 9,65$ & $36,22 \pm 7,06$ \\
\hline Max & 54,00 & 182,00 & 114,20 & 48,20 & 2007,00 & 49,60 & 56,60 & 67,80 & 49,60 \\
\hline Min & 21,00 & 154,00 & 53,30 & 18,10 & 1177,00 & 5,80 & 3,20 & 36,70 & 26,90 \\
\hline \multicolumn{10}{|l|}{ Zambrów } \\
\hline Average & $31,27 \pm 9,89$ & $163,47 \pm 4,05$ & $57,23 \pm 9,85$ & $21,38 \pm 3,34$ & $1284,07 \pm 107,52$ & $25,60 \pm 8,02$ & $15,27 \pm 7,36$ & $40,62 \pm 4,66$ & $30,73 \pm 2,67$ \\
\hline Max & 47,00 & 174,00 & 80,40 & 29,50 & 1500,00 & 39,70 & 31,00 & 49,40 & 36,20 \\
\hline Min & 19,00 & 157,00 & 46,10 & 17,10 & 1151,00 & 12,00 & 5,50 & 28,30 & 27,20 \\
\hline \multicolumn{10}{|l|}{ Sejny } \\
\hline Average & $25,69 \pm 6,55$ & $170,69 \pm 8,20$ & $73,76 \pm 13,30$ & $25,13 \pm 3,01$ & $1674,13 \pm 288,60$ & $24,64 \pm 8,12$ & $18,36 \pm 7,66$ & $55,42 \pm 10,86$ & $40,58 \pm 7,94$ \\
\hline Max & 45,00 & 182,00 & 98,50 & 32,20 & 2045,00 & 40,20 & 39,60 & 69,70 & 51,00 \\
\hline Min & 19,00 & 153,00 & 44,40 & 19,00 & 1148,00 & 12,30 & 7,90 & 36,30 & 26,60 \\
\hline \multicolumn{10}{|l|}{ Kolno } \\
\hline Average & $26,49 \pm 15,48$ & $127,01 \pm 73,26$ & $57,18 \pm 33,09$ & $20,96 \pm 12,92$ & $1182,26 \pm 652,09$ & $22,63 \pm 15,07$ & $19,45 \pm 16,22$ & $38,24 \pm 21,77$ & $28,56 \pm 15,89$ \\
\hline Max & 54,00 & 182,00 & 114,20 & 48,20 & 2045,00 & 49,60 & 56,60 & 69,70 & 51,00 \\
\hline Min & 6,55 & 4,05 & 9,85 & 3,01 & 107,52 & 5,80 & 3,20 & 4,66 & 2,67 \\
\hline \multicolumn{10}{|c|}{ Hajnówka } \\
\hline Average & $27,21 \pm 16,70$ & $123,91 \pm 70,12$ & $57,53 \pm 35,42$ & $21,58 \pm 14,52$ & $1169,23 \pm 674,35$ & $22,79 \pm 16,02$ & $20,57 \pm 18,51$ & $38,15 \pm 22,63$ & $28,40 \pm 16,62$ \\
\hline Max & 54,00 & 182,00 & 114,20 & 48,20 & 2045,00 & 49,60 & 56,60 & 69,70 & 51,00 \\
\hline Min & 6,55 & 4,05 & 9,85 & 3,01 & 107,52 & 5,80 & 3,20 & 4,66 & 2,67 \\
\hline
\end{tabular}

Bmi - body mass index, bmr - basal metabolic rate, fat\% - percentage fatty tissue content, fat mass - fatty tissue mass, lbm - lean body mass, twc - total water content Source: own elabotation

\section{References:}

1. Carnethon MR, Biggs ML, Barzilay JI i in. (2007), Longitudinal association between depressive symptoms and incident type 2 diabetes mellitus in older adults: the Cardiovascular Health Study. Arch. Intern. Med. 167: 802-807.

2. Dolecka M. (1997), Psychologiczne skutki bezrobocia. Anales UMCS Sectio, 31:14-24

3. Domienik J. Pruszczyk P. (2007), Otyłość jako czynnik ryzyka powikłań sercowo-naczyniowych. Przegląd Kardiologiczny 9(6): 432-436

4. Eliasson B. (2003), Cigarette smoking and diabetes. Progress in Cardiovascular Diseases, 45(5): 405-412

5. GUS - basic information about demographic development of Poland in years 2000-2010.

6. Katon W, Korff M, Ciechanowski P i in. (2004), Behavioral and clinical factors associated with depression among individuals with diabetes. Diabetes Care 27: 914-920.

7. Kłosiewicz-Latoszek L, Cybulska B. (2011), Cukier a ryzyko otyłości, cukrzycy i chorób sercowo-naczyniowych. Problemy Higieny i Epidemiologii 92(2): 181-186.

8. Kołodko G, (2002), Trzeba całość strategii gospodarczej podporządkować walce z bezrobociem. Nowe Życie Gospodarcze 14: 21. 
9. Korolkiewicz J. i in. (2009), Wskaźnik masy ciała a insulinooporność oraz parametry stresu oksydacyjnego u kobiet w podeszłym wieku. Gerontologia Polska, 2(17): 64-70.

10. Kostrzewski Sz., Worach-Kardas H. (2008), Zdrowotne i społeczno-ekonomiczne aspekty długotrwałego bezrobocia w środowisku wielkomiejskim. Problemy Higieny i Epidemiologii 89(4): 504-510.

11. Latalski M. i in. (2003), Wpływ bezrobocia na stan zdrowia i kształtowanie się zachowań zdrowotnych wśród osób pozostajacych bez pracy. Zdrowie Publiczne 113 (1/2): 174-177.

12. Latalski M. i in. (2004), Problemy zdrowotne bezrobotnych w makroregionie lubelskim. Zdrowie Publiczne 114(3): 271-274.

13. Latalski M. i in. (2004), Funkcjonowanie rodziny w sytuacji bezrobocia. Zdrowie Publiczne, 14(2): 131-134.

14. Latalski M. i in. (2002), Zdrowotne i społeczne konsekwencje bezrobocia. Pielęg. Położ 9: 8-11.

15. Linn M.W, Sandifer R, Stein S. (1985), Effects of unemployment on mental and physical health. Am J Public Health. 75(5): 502-506.

16. Martikainen P., Valkonen T. (1996), Excess mortality of unemployed men and women during a period of rapidly increasing unemployment. Lancet 348 (9032): 909-912.

17. Materiały Szkoleniowe Międzynarodowego Towarzystwa Badań nad Otyłością (IASO). red. ZahorskaMarkiewicz B. Archi-Plus 2009.

18. Montgomery S.M, Cook D.G, Bartley MJ, Wadsworth M.EJ. (1999), Unemployment pre - dates symptoms of depression and anxiety resulting in medical consultation in young man. International Journal of Epidemiology 28: 95-100.

19. Musselman DL, Betan E, Larsen H, Phillips LS. (2003), Relationship of depression to diabetes types 1 and 2 : epidemiology, biology, and treatment. Biol. Psychiatry 54: 317-329.

20. Obesity: Preventing and managing the global epidemic. Report of a WHO consultation. WHO Technical Report Series; Geneva, 2000, 894.

21. Pacholczyk M, Ferenc T, Kowalski J. (2008), Zespół metaboliczny. Patogeneza zespołu metabolicznego i jego powikłań. Postępy Higieny i Medycyny Doświadczalnej 62: 543-558.

22. Przybylik-Mazurek E, Huszno B, Leder M, Kieć-Klimczak M. (2006), Zaburzenia lipidowe w przebiegu cukrzycy typu 2 a współwystępowanie nadciśnienia tętniczego, choroby niedokrwiennej serca i otyłości. Endokrynologia, Otyłość, Zaburzenia Przemiany Materii 2(3): 86-93.

23. Przybyłowicz K. i in. (2008), Wskaźnik masy ciała a parametry gospodarki lipidowej kobiet $w$ okresie okołomenopauzalnym z województwa Warmińsko-Mazurskiego. Nowiny Lekarskie 77(4): 305-310 .

24. Robinson N, Yateman NA, Protopapa LE, Bush L. (1989), Unemployment and diabetes. Diabetic Medicine 6(9): 797-803.

25. Socha P. (2003), Znaczenia żywienia $w$ rozwoju dzieci i w profilaktyce chorób cywilizacyjnych. Klin. Pediat. 11(5), 557-560.

26. Talbot F, Nouwen A. (2000), A review of the relationship between depression and diabetes in adults: is there a link? Diabetes Care 23: 1556-1562.

27. Tatoń J., Czech A., Bernas M. (2007), Kliniczna definicja nadwagi i otyłości., Otyłość zespół metaboliczny. Wydawnictwo Lekarskie PZWL, Warszawa 26-41.

28. World Health Organization (1998), Diabetes Mellitus fact sheet. WHO, Geneva 138.

29. Zagożdżon P. Ejsmont J. (2008), Jakość życia zwiq̨zana ze zdrowiem u bezrobotnych. Problemy Higieny i Epidemiologii. 89(4): 498-503.

30. Zahorska-Markiewicz B. (2009), Postępowanie $w$ otyłości dorosłych: europejskie wytyczne dla praktyki klinicznej. Endokrynologia, Otyłość i Zaburzenia Przemiany Materii 5(3): 87-98.

31. Żyto-Uramowska B. Wojciechowska-Kozłowska M. (2003), Zachowania żywieniowe rodzin ubogich. Roczniki PZH, 54(2): 221-229.

Submitted: 28.07.2014

Accepted: 17.09.2014 